\title{
Effect of Different Phosphorus Fertilizer Rates on Growth, Dry Matter Yield and Yield Components of Common Bean (Phaseolus vulgaris L.)
}

\author{
Meseret Turuko, Amin Mohammed* \\ Department of Plant Sciences, College of Agriculture and Veterinary Sciences, Ambo University, Ethiopia \\ *Corresponding author: aminmahammed@gmail.com
}

Received March 23, 2014; Revised April 14, 2014; Accepted April 16, 2014

\begin{abstract}
Common bean (Phaseolus vulgaris L.) is an important cash crop and protein source for farmers in many parts of Ethiopia. However, its production is limited by phosphorus fertilizer. Therefore, field experiment was conducted at the Arba Minch farm field the main rain season of 2011 to investigate the responses of common bean to different levels of phosphorus fertilizer and its effect on growth, dry matter yield and yield component of the crop. Five phosphorus rates $\left(0,10,20,30\right.$ and $\left.40 \mathrm{~kg} \mathrm{ha}^{-1}\right)$ were used as treatments. Red Wolaita common bean variety was used as planting material. Recommended rate of $\mathrm{N}(60 \mathrm{~kg} / \mathrm{ha}$ ) was applied to all treatments. The experiment was laid out in a randomized complete block design with three replications. The effect of phosphorus was significantly increased dry matter yield, yield components and growth parameters such as leaf area and number of branches per plant, whereas its effect was not significant on plant height. Based on result obtained, application of 20P kgha ${ }^{-1}$ is recommended for better production of common bean at Arba Minch and similar areas which have the same soil property.
\end{abstract}

Keywords: common bean, Diammonium phosphate, dry matter, phosphorus

Cite This Article: Meseret Turuko, and Amin Mohammed, "Effect of Different Phosphorus Fertilizer Rates on Growth, Dry Matter Yield and Yield Components of Common Bean (Phaseolus vulgaris L.).” World Journal of Agricultural Research, vol. 2, no. 3 (2014): 88-92. doi: 10.12691/wjar-2-3-1.

\section{Introduction}

Common bean is high in starch, protein and dietary fiber and is an excellent source of potassium, selenium, molybdenum, thiamine, vitamin B6, and folic acid [1]. It is used as foods tuff and the green unripe pods are cooked or conserved as vegetable. The ripe seeds cooked for soups and broth in the world [2].

In Ethiopia, common bean is one of the most important cash crops and source of protein for farmers in many lowlands and mid-altitude zones. The country's export earnings is estimated to be over $85 \%$ of export earnings from pulses, exceeding that of other pulses such as lentils, faba bean and chickpea [3]. Common bean ranks third as an export commodity in Ethiopia, contributing about $9.5 \%$ of total export value from agriculture [4]. Total national production was estimated at 421,418 ton in 2008, with a market value of US\$ 132,900,609 million [4]. Common bean is also highly preferred by Ethiopian farmers because of its fast maturing characteristics that enables households to get cash income required to purchase food and other household needs when other crops have not yet matured [5].

Common bean has high nitrogen requirement for expressing their genetic potential. However, as bean has the ability to fix and use atmospheric nitrogen with regards to soil fertility and mineral nutrition requirement, phosphorus is considered as the first and nitrogen as the second limiting plant nutrient for bean yield in the tropical zone of cultivation [6]. Moreover, phosphorus plays an important role in biological nitrogen fixation. For the symbiotic fixation of nitrogen to occur, the roots have to interact with compatible rhizobia in the soil and factors that affect root growth or the activity of the host plant would affect nodulation [7]. Bacterial growth, nodule formation, and the biological nitrogen fixation activity itself are processes that are dependent on the energy supplied from the sugars that need to be transacted down ward from the host plant shoots. Therefore, phosphorus is the basis for the formation of useful energy, which is essential for sugar formation and translocation $[8,9]$ reported that common bean crop dependent on nitrogen fixation needs more inorganic phosphorus than the same crop provided with mineral nitrogen. Beans are therefore especially susceptible to low soil phosphorus when accompanied by low soil.

Phosphorus availability in soil is a major constraint to common bean production in the tropics [10]. From the essential plant nutrients, nitrogen and phosphorus are often deficient in many soils of tropical Africa as well as in many Ethiopian soils [11]. In the tropics, the amount of available phosphorus in soils is largely in sufficient to meet the demand of legumes and thus phosphorus deficiency is widespread in pulse crops [12]. To overcome 
such problem the research is needed to know optimum rate of phosphorus nutrient for common ban production. However in Ethiopia 69kg $\mathrm{P}_{2} \mathrm{O}_{5} /$ ha recommended for common bean production in semi-arid zones of Central Rift Valley [13].

So far, no works have been conducted on determination of optimum phosphorus fertilizer rate for production of common bean at Arba Minch, Ethiopia. Therefore, there is a need to acquire of information on influences of phosphorus in growth, dry matter yield and yield component of common bean and to know optimum rate of fertilizers in study area. Thus, this study was initiated with the following objectives: (1) to evaluate the effect of different phosphorus fertilizer rates on growth, dry matter yield and yield components of common bean,(2) to identify the optimum rate of phosphorus fertilizer on growth, dry matter yield and yield components of common bean.

\section{Materials and Methods}

\subsection{Description of Study Area}

The experiment was carried out at Arba Minch University research farm field which is located $500 \mathrm{~km}$ from Addis Ababa, the capital city of Ethiopia. It has an altitude of 1218 m.a.s.l, longitude of $37.36^{\circ} \mathrm{E}$ and $6.04^{\circ} \mathrm{N}$. In Arba Minch, there are two months where the area rain fall sets high amount in April and May are 161.8mm and $151.2 \mathrm{~mm}$ respectively and the lowest rain fall appears in January and February are $32 \mathrm{~mm}$ and $9 \mathrm{~mm}$ respectively. The annual rainfall is $500-1100 \mathrm{~mm}$, the annual air temperature is $17-39^{\circ} \mathrm{C}$ and the soil temperature is 22$35^{\circ} \mathrm{C}$ in different depth of soil.

\subsection{Experimental Design and Treatments}

The experiment was laid out in randomized complete block design (RCBD) with five treatments of phosphorus fertilizer rates $\left(0,10,20,30\right.$, and $\left.40 \mathrm{~kg} \mathrm{ha}^{-1}\right)$ and three replications to evaluate the effect phosphorus on growth and dry matter yield of common bean (Phaseolus vulgaris L.) variety Red Wolaita. The size of each experimental unit was $\left.1.6 \mathrm{~m} \mathrm{X} \mathrm{1.5m} \mathrm{(2.4} \mathrm{m}^{2}\right)$ having four rows, each contains 10 plants. A distance of $1 \mathrm{~m}$ and $1.5 \mathrm{~m}$ were left between plots and blocks, respectively. Two seeds per hole were sown at the recommended planting depth of 6 $\mathrm{cm}$ with spacing of $40 \mathrm{~cm}$ between rows and $10 \mathrm{~cm}$ between plants. Thinning of one seedling per hole was carried out after 15 days from sowing. Diammonium phosphate (DAP) was used as a source of phosphorus and full doses which varied depending on treatments were applied as side banding at sowing time. Urea was used as starter and to make a uniform $60 \mathrm{~kg} \mathrm{ha}^{-1}$ application on each treatment unit. Similarly, other agronomic practices were kept uniform for all treatments as recommended and adopted for the location.

\subsection{Soil Sample Collection and Laboratory Analysis}

Soil samples, 0 to $30 \mathrm{~cm}$ depth, were collected from representative spots of the entire experimental field by using diagonal sampling method before planting and the composite sample was obtained. The soil was air dried and made fine by using mortar and pestle. The fined soil was passed through $2 \mathrm{~mm}$ sieve and the soil textural class, $\mathrm{p}^{\mathrm{H}}$, and EC were determined in Arba Minch university soil Laboratory. The $\mathrm{p}^{\mathrm{H}}$ (1:25 solid: liquid ratio) of the soil was measured in water using $\mathrm{p}^{\mathrm{H}}$ meter. The electrical conductivity of the soil was determined by using EC meter. The soil texture was analyzed by Bouyoucos hydrometer method and the textural class was determined by using the soil textural triangle. The soil moisture was determined by gravimetric sampling method.

\subsection{Agronomic Data Collections and Analysis}

Data on plant height, leaf area, number of branches per plant, number of pods per plant, number seed per pod and dry matter yield were taken from ten pre tagged plants of each two middle rows. The plant height was measured from the base of the plant to the apical bud of plant and expressed in centimeters. Total leaf area was recorded by measuring maximum length $(\mathrm{mL})$ and width $(\mathrm{mW})$ of trifoliate leaves and multiplying these inputs ( $\mathrm{mL} \times \mathrm{mW}$ ) by a correction factor of 0.6 derived from the actual leaf area determined by using a leaf area meter. The number of branches per plant was recorded by counting number branches from each ten pre tagged plants and the mean was taken as number of branches per plant. Pods from pre tagged plants were counted and average was recorded as number of pods per plant. Seeds per pod counted from ten randomly selected pre tagged plants was converted to mean value and recorded as number of seeds per pod. Dry matter yield was obtained by ten randomly selected pre tagged plants were cut above the ground and partitioned into different parts viz. leaf, stem and reproductive parts. The samples were oven dried at $80^{\circ} \mathrm{C}$ to a constant weight and weights were recorded. The means recorded as dry matter of the plant (gm).

\subsection{Statistical Analysis}

Data on plant height, leaf area, number of branches per plant, number of pods per plant, number seed per pod and dry matter yield were statically analyzed using the SAS version 9.2 software and means were compared using LSD at a probability level of $5 \%$.

\section{Results and Discussion}

\subsection{Soil Analysis}

The physical and chemical properties of the soil before sowing were presented in (Table 1). The soil texture of experimental was clay loam. The $\mathrm{pH}$ value the experimental soil was 7.3 slightly basic. The electrical conductivity (Ec) was $4.46 \mu \mathrm{s} / \mathrm{cm}$. The soil moisture content of experimental of soil was 10.49 .

Table 1. Physical and chemical properties of the top soil $(0-30 \mathrm{~cm})$ used in the field experimental site in Arba Minch Research farm field

\begin{tabular}{|c|c|c|c|c|}
\hline \multirow{2}{*}{$\begin{array}{c}\text { Soil depth } \\
\text { (cm) }\end{array}$} & \multicolumn{2}{|c|}{ Physical properties of soil } & \multicolumn{2}{|c|}{ Chemical properties of soil } \\
\cline { 2 - 5 } & $\begin{array}{c}\text { Textural } \\
\text { class }\end{array}$ & $\begin{array}{c}\text { Moisture } \\
\text { content }\end{array}$ & $\mathrm{pH}$ & $\begin{array}{c}\text { Conductivity } \\
(\text { EC in } \mu \mathrm{s} / \mathrm{cm})\end{array}$ \\
\hline $0-30$ & Clay loam & 10.49 & 7.3 & 4.46 \\
\hline
\end{tabular}


The mean square estimates for the source of variation studied was presented in Table 2. There was significant difference among treatments on phosphorus rates $(0,10$, 20, 30, and $\left.40 \mathrm{~kg} \mathrm{ha}^{-1}\right)$. Highly significant $(\mathrm{P}<0.01)$ and significant $(\mathrm{P}<0.05)$ were observed on growth parameters and yield components. The applied $\mathrm{P}$ fertilizer levels

Table 2. Analysis of variance on the effect of different rates of phosphorus fertilizer onplant height, leaf area, pods/plant, branch number, seeds/pod and dry matter at Arba Minch, southern Ethiopia

\begin{tabular}{|c|c|c|c|c|c|c|c|}
\hline Source of Variation & Df & Plant height $(\mathrm{Cm})$ & Leaf area $(\mathrm{Cm} 2)$ & Branch no. & Pods/plant & Seeds/pod & DM (gm) \\
\hline Replication & 2 & $64.414 \mathrm{~ns}$ & $194.97 \mathrm{~ns}$ & $0.22 \mathrm{~ns}$ & $396.22 *$ & $0.18 \mathrm{~ns}$ & $264.47 *$ \\
\hline Treatment & 4 & $928.4697 \mathrm{~ns}$ & $1921.07 *$ & $4.99 *$ & $263.57 *$ & $3.02 *$ & $816.37^{* *}$ \\
\hline Error & 8 & 272.39 & 279.03 & 0.98 & 55.65 & 0.42 & 51.37 \\
\hline
\end{tabular}

$\mathrm{Df}=$ degree of freedom, DM=dry matter, Ns-Statistically not significant *Significant at $\mathrm{P}<0.05$ and $* *$ significant at $\mathrm{P}<0.01$.

\subsection{Effect of Different Rates of Phosphorus Fertilizer on Plant Height, Leaf Area and Number of Branchesper Plant}

The $\mathrm{P}$ application at all rates except at $\mathrm{P} 40 \mathrm{~kg} \mathrm{ha}^{-1}$, resulted in significant higher leaf area than the control (Table 3). The highest leaf area $\left(119.8 \mathrm{~cm}^{2}\right)$ and $(99.86$ $\mathrm{cm}^{2}$ ) were recorded at rate application of P $20 \mathrm{~kg} \mathrm{ha}^{-1}$ and $30 \mathrm{~kg} \mathrm{ha}^{-1}$, respectively. In contrast, the lowest leaf area of (53.03 $\mathrm{cm}^{2}$ ) was recorded from the treatment with application of $40 \mathrm{~kg} \mathrm{P} \mathrm{ha}{ }^{-1}$.This result was in agreement with that the application of $75 \mathrm{~kg} \mathrm{P}_{2} \mathrm{O}_{5}$ ha $^{-1}$ was significantly increased leaf area over rest level reported by [14]. Similarly, significant increase in leaf area was observed with increment in P application from 25 to $75 \mathrm{~kg}$ $\mathrm{ha}^{-1}$ [15]. However, decrease in leaf area, even less than control at application rate of $\mathrm{P} 40 \mathrm{~kg} \mathrm{ha}^{-1}$ might be due to $\mathrm{P}$ response dependence on available $\mathrm{P}$ in study site and when it is above the optimum level it may interrupt other

Table 3. Effect of different rates of phosphorus fertilizer on

Table 3. Effect of different rates of phosphorus fertilizer on growth, dry matter yield and yield component of common bean
\begin{tabular}{|c|c|c|c|c|c|}
\hline Phosphorus rates kg/ha & Plant height $(\mathrm{cm})$ & Leaf area $\left(\mathrm{cm}^{2}\right)$ & Number of Branches/plant & Pods/plant & Seeds/pod \\
\hline 0 & 91 & 57.673 & 2.33 & 24.83 & 31.16 \\
\hline 10 & 96.83 & 79.07 & 4 & 48.16 & 5.16 \\
\hline 20 & 125.5 & 119.8 & 5.67 & 39.67 & 5.81 \\
\hline 30 & 114.41 & 99.86 & 5 & 30.33 & 4.20 \\
\hline 40 & 82.41 & 53.03 & 3.58 & 21.4 & 13.19 \\
\hline CV (\%) & 19.55 & 19.766 & 24 & 14.04 & 1.2 \\
\hline LSD (5\%) & NS & 31.45 & 1.84 & & 2 \\
\hline
\end{tabular}

The application of $\mathrm{P}$ fertilizer significantly affected the number of branches per plant (Table 3). The number branch per plant increased with increasing phosphorus application rates up to optimum level. The highest number of branches per plant (5.67) was recorded at rate of $20 \mathrm{~kg}$ $\mathrm{P}$ ha $^{-1 .}$ This is also similar to result reported by[14], significantly higher number of branches per plant is recorded with $75 \mathrm{~kg} \mathrm{P}_{2} \mathrm{O}_{5} \mathrm{ha}^{-1}$. The Mean of $\mathrm{P}$ fertilizer applied revealed significantly higher number of branches per plant over control. The lowest number of branches per plant (2.33) was recorded at control. The increment in number of branches per plant might be importance of $\mathrm{P}$ for cell division activity, leading to the increase of plant height and number of branches and consequently increased the plant dry weight [18]. revealed significant differences on dry matter yield, leaf area, number of branches per plant, number of pods per plant, and seeds per pod. On the other hand, application of different rates of $\mathrm{P}$ fertilizer did not significantly affect $(\mathrm{P}<0.05)$ plant height.

nutrients, which in turn can bring decrease in growth of bean.

As indicated in Table 3, application of $\mathrm{P}$ fertilizer has no significant effect on plant height. The high plant height $\left(125.5 \mathrm{~cm}^{2}\right)$ was recorded on application rate of $20 \mathrm{~kg} \mathrm{P}$ $\mathrm{ha}^{-1}$. Moreover, application of $30 \mathrm{~kg} \mathrm{P} \mathrm{ha}^{-1}$ has revealed high plant height $\left(114.41 \mathrm{~cm}^{2}\right)$ next to $\mathrm{P} 20 \mathrm{~kg} \mathrm{ha}^{-1 .}$ On the other hand, there was no significant difference between means of applied P fertilizer rates. This result is similar to the result reported by [16], a non- significant response of plant height to $\mathrm{P}$ application on common bean. The lowest plant height $\left(82.41 \mathrm{~cm}^{2}\right)$ was recorded at high application of $\mathrm{P}$ rate, this confirms with the lowest plant height was recorded at application rate of $\mathrm{P} 40 \mathrm{~kg} \mathrm{ha}^{-1}$ reported by [17]. The highest rate of $\mathrm{P}$ application at the study site had no effect on plant height. This might be due to high dose of phosphorus fertilizer tends to form nutrient interaction and may affects the availability of other nutrients which are essential for growth of the bean.

\subsection{Effect of Different Rates of Phosphorus Fertilizer on Number of Pods per Plant and Number of Seeds per Pod}

Application of $\mathrm{P}$ fertilizer had significantly increased the number of pod per plant (Table 3).Significantly higher number of pods per plant (48.16) was recorded with $\mathrm{P}$ rates of $20 \mathrm{~kg} \mathrm{ha}^{-1}$ over rest of the levels. All applied $\mathrm{P}$ fertilizer rates significantly increased pods per plant over the control. The lowest pods per plant (24.83) were recorded at control (no application of $\mathrm{P}$ fertilizer).The result is similar to [14], reported that applications of different rates of phosphorus fertilizer influence number of pod per plant. Similarly, [15] observed significantly more number of pods per plant of common bean at 
application rate of $75 \mathrm{~kg} \mathrm{P}_{2} \mathrm{O}_{5}$ ha. Also, [19] reported significant increase in number of pods per plant, due to increased $\mathrm{P}$ fertilization. Thus the increment of number of pods per plant due to application of $\mathrm{P}$ fertilizer confirms with Pfertilizer promotes the formation of nodes and pods in legumes [20].

The analysis of variance for seeds per pod (Table 2) showed significant response to Prates levels. The highest number of seeds per pod (5.85) was obtained at applied P rate of $20 \mathrm{~kg} \mathrm{ha}^{-1}$, whereas the lowest seed per pod (3.14) was recorded in the control treatment. The result of the present study were in agreement with the findings of [14]who reported that number of seeds per pod increased significantly to levels of phosphorus added. The increment of seeds per pod with increasing $P$ fertilizer application up to optimum level might be $\mathrm{P}$ fertilizer for nodule formation, protein synthesis, fruiting and seed formation.

\subsection{Effect of Different Rates of Phosphorus Fertilizer on Common Bean Dry Matter Yield}

The applied rates of $\mathrm{P}$ fertilizer have significantly increased the dry matter yield of common bean at the probability level of 0.05 and 0.01 . There was a significant difference among five levels $\mathrm{P}$ fertilizer rates (Figure 1 ). The maximum (75.5gm plant ${ }^{-1}$ ) dry matter yield was recorded at application of $\mathrm{P} 20 \mathrm{~kg} \mathrm{ha}^{-1}$, where as the minimum (28.9 gm plant ${ }^{-1}$ ) was recorded on control. This result was similar to [14] who reported dry matter accumulation increase with application of phosphorus rates. Similarly, significant and linear increase in total dry matter production of common bean plant was observed due to increased phosphorus [15].This is in agreement with the study conducted on soybean indicated that increasing the phosphorus concentration in the soil increased the whole plant dry matter accumulation and total leaf area [21]. This increment in dry matter yield with application of $\mathrm{P}$ fertilizer might be due to the adequate supply of $\mathrm{P}$ could be attributed to an increase in number of branches per plant, and leaf area. This in turn increased photosynthetic area and number of pods per plant, which demonstrates a strong correlation with dry matter accumulation and yield.

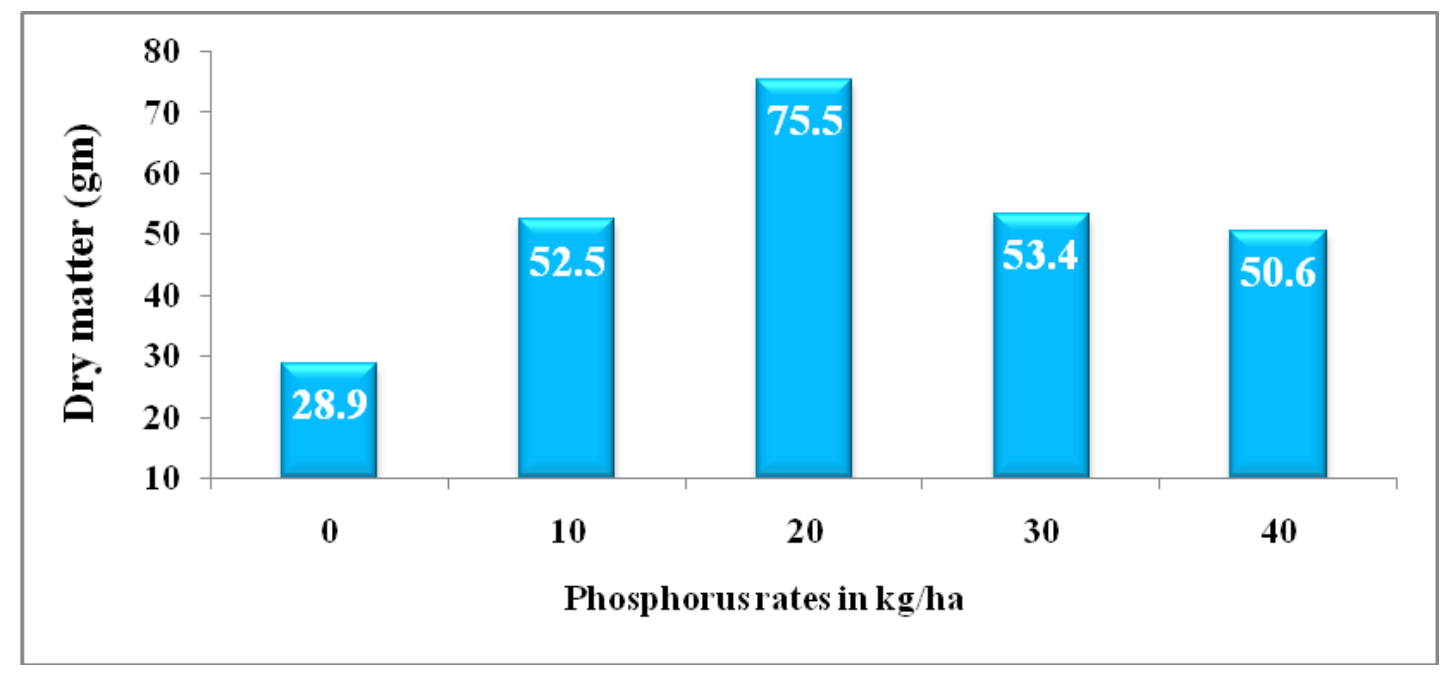

Figure 1. Effect of different rates of phosphorus fertilizer on dry matter of common bean at Arba Minch, southern Ethiopia

\section{Conclusions}

Application of the correct level of fertilizer is necessary to achieve maximum yield of common bean crop. The present study was initiated to assess the influence of different levels of phosphorus on growth, dry matter yield and yield component of common bean. The Physical and chemical properties of soil was collected before planting. The applied P fertilizer levels were revealed a significant difference on leaf area, number of branch per plant, number of pods per plant, seeds per pod and dry matter yield. The application P $20 \mathrm{~kg} \mathrm{ha-1}$ has significantly increased dry matter yield, yield components and all growth parameters, except plant height over the rest levels. While, application of $40 \mathrm{~kg} \mathrm{P} \mathrm{ha}{ }^{-1}$ was declined plant height and leaf area as compared to control. Thus, Based on the result obtained, it was possible to conclude that phosphorus fertilizer rate of $20 \mathrm{~kg} \mathrm{ha}^{-1}$ was promising to enhance yield of common bean in Arba Minch, Southern Ethiopia. In general it recommended that investigating the same study in different localities to have a real recommendation for the optimum level of $\mathrm{P}$ fertilizer to produce common beam. In addition, it is important to know the mineral content of the soil that hinders the uptake of phosphorus by the plant.

\section{References}

[1] Maiti, R.K. and Singh, V.P., Advances in Common Bean and Related Species, $1^{\text {st }}$ edit. Publisher: Agro bios (International).Pp 12. Plant Physiology. 84: 835-840. 2007.

[2] Brucher H., Trop., Nutzpfl. Springer V. and Wolf G., Distribution, Yield and Use of CommonBean.Availableat: http://www2.mpiz.koeln.mpg.de/pr/garten/schau/phaseolusvulgari s/commonbean.ntml). Via internet accessed 2011Janu.20. 1977.

[3] Negash R., "Determinants of adoption of improved haricot bean production package in Alaba special woreda, southern Ethiopia”. MSc Thesis, Haramaya University. 2007.

[4] FAOSTAT., Food and Agriculture Organization at www.fao.org. 2010.

[5] Legesse D.G., Kumssa T., Assefa M., Taha J., Gobena T., Alemaw A., Abebe Y., Mohhamed and Terefe H., Production and Marketing of White Pea Beans in the Rift Valley, Ethiopia. A SubSector Analysis. National Bean Research Program of the Ethiopian Institute of Agricultural Research. 2006.

[6] CIAT (Centro Internationalede Agricultural Tropical), Bean project annual report 1997. CIAT Working Document No.177.CIAT. Cali, Colombia. 1998. 
[7] Freire J.R. Important limiting factors in soil for the rhizobiumlegume symbiosis.In; Alexander M (ed), BNF: Ecology, Technology and Physiology, Plenum Press, New York. PP. 75-98. 1984.

[8] Graham P.H., Plant factors affecting nodulation and symbiotic fixation in Legumes. In; Alexander M., Plenum press, New York. PP. 75-98. 1984.

[9] Israel D.W., Investigation of the role of Phosphorus in symbiotic nitrogen fixation. Plant Physiology. 84: 835-840. 1987.

[10] Allen D.J., Ampofo K.A. and Wortmann C.S., Field Problems of beans in Africa. CITA and Centre for Tropical Agriculture (CTA). International Lvestock Research Institute (ILRI), Addis Ababa. 1997.

[11] Ngugi D.N., Agronomic concepts of potato with reference to increasing thepotential yield under tropical conditions. Potato seed production for Tropical Africa. CIP Lima, Peru. 1982.

[12] Rao I.M., Friesen D.K. and Osaki M., Plant adaptation to Phosphorus-limited Tropical soils. Hand book of plant and crop stress, Marcel Dekker Inc., PP. 61-65. 1998.

[13] Girma A., "Effect of Np Fertilizer and Moisture Conservation on the Yield and Yield Componentsof Common bean (Phaseolus Vulgaris L.) In the Semi Arid Zones of the Central RiftValley in Ethiopia”.Advances in Environmental Biology, 3(3): 302-307. 2009.

[14] Shubhashree K.S., "Response of Rajmash (Phaseolus Vulgaris L.) To The Levels of Nitrogen, Phosphorus and Potassium during Rabi in the Northern Transition Zone”. 2007.
[15] Veeresh N.K., "Response of French bean (Phaseolus vulgaris L.) to fertilizer levels in Northern Transitional Zone of Karnataka" M.Sc. (Agri.)Thesis, Univ. Agric. Sci., Dharwad. 37-79. 2003.

[16] Birhan Abdulkadir, "Response of common bean (Phaseolus vulgaris L.) to nitrogen, phosphorus and inoculation of Rhizobium Leguminosarumon yield and yield components at Melkassa", M.Sc. Thesis, University of Hawassa, Awassa College of Agriculture, Ethiopia, 97. 2006.

[17] Eden T. "Study on uptake and response of common bean (Phaseolus vulgaris L.) varieties to different levels of phosphorus application on entisol of Alemaya”. MSC. Thesis. Harmaya University, Haramaya, Ethiopia. 2003.

[18] Tesfaye M.J., Liu D.L., Allan and Vance C.P., Genomic and genetic control of phosphate stress in legumes. Plant Physiol., 144 594-603.2007.

[19] Singh A.K. and Singh S.S., "Effect of planting dates, nitrogen and phosphorus levelson yield contributing characters in French. 2000.

[20] Buttery B.R. "Analysis of the growth of soybeans as affected by plant population and fertilizer". Canadian Journal of Plant Science. 49: 675-684. 1969.

[21] Jennifer D.C., "Phosphorus stress effects on growth and seed yield responses of nodulated soybean to elevated carbon dioxide". Journal of Agronomy and Crop Science. 80: 897-99. 1988. bean”, Legume Res., 23: 33-36. 2000. 